\title{
Caliphal Estates and Properties around Medina in the Umayyad Period
}

\author{
Harry Munt
}

In an article published in 1977, Meir J. Kister first drew scholars' attention to the important social and political implications of the Umayyad caliphs' accumulation of agricultural estates in the area around Medina. ${ }^{1}$ In this investigation of the causes of the Battle of the Harra - which took place in Dhū l-Hijja 63/August 683 between the Medinans and an army under the command of Muslim b. 'Uqba sent from Syria by the caliph Yazīd b. Mu'āwiya (r. 6o-64/68o-683) Kister studied the testimony of a number of sources which led him to conclude convincingly that, "The battle of the Harra is thus seen to be the result of a conflict between the owners of estates and property in Medina and the unjust Umayyad rulers who robbed them of their property." In spite of the attention paid to landholding patterns in other regions of the Islamic world, the important implications of Kister's conclusion, which draws attention to the importance that land ownership has played in the political history of Medina, have hardly been researched further. ${ }^{3}$ Perhaps the most important ques-

1 Meir J. Kister, "The Battle of the Harra: Some Socio-Economic Aspects," in Studies in Memory of Gaston Wiet, ed. Myriam Rosen-Ayalon (Jerusalem: The Hebrew University of Jerusalem, 1977), 33-49. Kister was building in part upon the important earlier studies of Henri Lam-

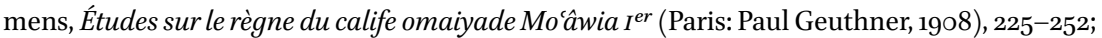
Henri Lammens, "Le califat de Yazîd I er," Mélanges de l'Université Saint Joseph 5 (1910-1912): 210-225, 237-257; 6 (1913): 401-411; Șālih Ahmad al-'Alī, "Muslim Estates in Hidjaz in the First Century A.H.," Journal of the Economic and Social History of the Orient 2 (1959): 247-261; Șāliḥ Aḥmad al-'Alī, "Milkiyyāt al-arāḍī fỉ l-Hijāāz fī l-qarn al-awwal al-hijrī," Majallat al-'arab 3 (1389/1969): 961-1005. Some further useful data can also be found in Șālị Aḥmad al-'Alī, "Studies in the Topography of Medina (During the first Century A.H.)," Islamic Culture 35 (1961): 65-92.

2 Kister, "Battle," 49.

3 At least not for the Islamic period; that conflict over land was important in pre-Islamic tensions in the town has been demonstrated by Isaac Hasson, "Contributions à l' étude des Aws et des Hazrağ," Arabica 36 (1989): 1-35; see also Michael Lecker, Muslims, Jews and Pagans: Studies on Early Islamic Medina (Leiden: Brill, 1995). Some further interesting material on land and estates around Medina in the Umayyad period can be found, for example, throughout Albert Arazi, "Matériaux pour l'étude du conflit de préséance entre la Mekke et Médine," Jerusalem

(C) THE AUTHOR, 2019 | DOI:10.1163/9789004386549_015

This is an open access chapter distributed under the terms of the CC-BY-NC 4.o license. 
tion that arises is, if the acquisition of estates around Medina by the Umayyad caliphs and their close relatives was so unpopular, why did they go to sometimes considerable lengths to acquire them? Were there simply large potential profits to be made, or should we seek alternative reasons?

The lack of further study into agricultural estates in the Hijāz in the Umayyad period is in no small part due to the paucity of decent sources. There is fairly little relevant archaeological, epigraphic and documentary material. ${ }^{4}$ There are plenty of literary sources - Medina inspired a lively local historical tradition, and works of other genres discuss the town to varying extents - but these were mostly written long after the fall of the Umayyad family in Syria and usually discuss estates only incidentally. That said, there is some very interesting material preserved in these later sources; of particular interest we can single out Ibn Shabba's (d. 262/876) Ta'ikikh al-Madina al-munawwara, ${ }^{5}$ and the numerous citations from Ibn Zabāla's (wr. 199/814) lost Akhbār al-Madīna preserved by later local historians such as al-Samhūdī (d. 911/15o6). ${ }^{6}$

This paper makes use of the material that can be found scattered across these sources to investigate the phenomenon of Umayyad family landholding and estate acquisition in the Hijāz, focusing to some extent on the role played in these endeavours by the Umayyad caliphs themselves. In many ways, it will confirm how little we know rather than what we do know, but there are two principal objectives related to this volume's theme of authority and control. The first is to understand how the Umayyads' estates around Medina were acquired, administered and worked, and the second is to grapple with why Umayyad caliphs risked unpopularity in Medina by using their position of power to acquire their land in the region. ${ }^{7}$ Was there an expected pay-

Studies in Arabic and Islam 5 (1984): 177-235; Michael Lecker, "Biographical Notes on Ibn Shihāb al-Zuhrī," Journal of Semitic Studies 41 (1996): 50-57; Jairus Banaji, "Late Antique Legacies and Muslim Economic Expansion," in Money, Power and Politics in Early Islamic Syria: A Review of Current Debates, ed. John F. Haldon (Farnham: Ashgate, 2010), 169-170.

4 Some of the relevant archaeological and epigraphic evidence will be referred to later in this paper, but for some indication of what has been done and is being done, see the various issues of the journals al-Ațläl, Proceedings of the Seminar for Arabian Studies and Arabian Archaeology and Epigraphy.

5 Ibn Shabba, Ta’rīkh al-Madina al-munawwara, eds. 'Alī Muhammad Dandal and Yāsīn Sa'd al-Dīn Bayān, 2 vols. (Beirut: Dār al-kutub al-ilmiyya, 1417/1996).

6 al-Samhūdī, Wafẳ al-wafā bi-akhbār dār al-mușțafā, ed. Qāsim al-Sāmarrāīì, 5 vols (London: Mu'assasat al-Furqān, 1422/2001). For a study of the citations from Ibn Zabāla's lost Akhbār al-Madina, see Harry Munt, "Writing the History of an Arabian Holy City: Ibn Zabāla and the First Local History of Medina," Arabica 59 (2012): 1-34.

7 This paper focuses on the area around Medina and the northern Hijāz (i.e. not Mecca and alȚầif with their hinterlands), and only on agricultural - and very occasionally commercial - 
off, in terms of the Umayyad family's ability to exercise their authority in the region, that compensated for the opposition such efforts at controlling the land engendered? A third, much looser aim is to see to what extent some general trends that can be seen in other regions of the world of late antiquity - for example, the more intensive and extensive exploitation of land for agriculture, and developments in patterns of landholding - impacted upon the western Arabian Peninsula in the early Islamic period. Such trends have frequently been linked to the abilities of certain groups to exercise authority over others, and it is important to begin to investigate what role landholding may have played in the Umayyad family's efforts to control a region as important as the Hijāz. ${ }^{8}$

The most prolific acquirers of land around Medina throughout the period of Umayyad rule appear to have been the various branches of the Umayyad family itself, with the Zubayrids and Alids - that is the descendants of the Prophet's originally Meccan Companions al-Zubayr b. al-Awwām (d. 36/656) and 'Alī b. Abī Țālib (d. 40/661) - following behind them. ${ }^{9}$ The families of the Meccan Companions 'Abd al-Rahmmān b. 'Awf (d. ca. 31/651-652) and Ṭalḥa b. 'Ubayd Allāh (d. 36/656), and their descendants, also appear as prominent estate owners. The relatives of other Meccan Companions, including 'Amr b. al-Āṣ (d. ca. 42/662-663), the conqueror of Egypt, and Sa'd b. Abī Waqqāṣ (d. 5os/67os), who led the conquest of Iraq, also had properties in the region. The relative lack of estates said to have been owned by Anșārī families - that is the descendants

possessions (i.e. not residential or administrative properties). On the southern Hijāz see, for example, Lammens, Études, 237-248; George C. Miles, "Early Islamic Inscriptions near Ṭāiif in the Hijāz," Journal of Near Eastern Studies 7 (1948): 236-242; Meir J. Kister, "Some Reports concerning Mecca: From Jāhiliyya to Islam," Journal of the Economic and Social History of the Orient 15 (1972): 84-91.

8 On estates in late antiquity, see for example Jairus Banaji, Agrarian Change in Late Antiquity: Gold, Labour, and Aristocratic Dominance, 2nd ed. (Oxford: Oxford University Press, 2007), 171-189; Chris Wickham, Framing the Early Middle Ages: Europe and the Mediterranean, 400-800 (Oxford: Oxford University Press, 2005), 153-302. On the intensification of agriculture and its spread into new lands in the late antique Near East, see also Michael Decker, Tilling the Hateful Earth: Agricultural Production and Trade in the Late Antique East (Oxford: Oxford University Press, 2009), 174-227.

9 For a concise discussion of some Alid properties, see Ibn Shabba, Ta’rīkh al-Madinna, 1:136141. 
of those who had lived in Medina before Muhammad's hijra - is noticeable. ${ }^{10}$ At the time of the hijra in 1/622, the Medinan Sad b. al-Rabī' (d. 3/625) was said to have owned the greatest number of properties in Medina (akthar ahlalMadina $\left.m \bar{a} l^{a n}\right),{ }^{11}$ but he granted half of his properties to the Meccan emigrant 'Abd al-Rahmān b. 'Awf after the Prophet had declared the two of them to be "brothers."12 We do hear about some Anșārī estate owners, but they are relatively few and far between. For example, during the reign of al-Walìd b. 'Abd al-Malik (r. 86-96/705-715), we read about estates belonging to the Anșārī Abū Bakr b. Muhammad b. 'Amr b. Hazm (d. 120/737-738), but only in the context of their confiscation by the authorities. ${ }^{13}$

These cultivated estates presumably did not cover Medina's entire hinterland, and we should note that much of the region's economic activity was pastoral and doubtless stock-raising took up much land. In fact, it is worth noting here that Medina's status as a sacred space, increasing over the Umayyad period, may have placed some restrictions upon agriculture around the town. Medina and its surroundings came by the late second/eighth and early third/ ninth centuries at least to be recognized widely by many Muslims (the main exceptions whose opinions are known to us were scholars associated with the Iraqi Abū Ḥanifa [d. 150/767]) to be a sacred enclave, specifically a haram, and one of the accompanying rules restricted the usage of plants (variously defined) in that area (the boundaries were also debated). ${ }^{14}$ Given the existence

10 For an overview of estate owners and their important properties in the Umayyad period, see al-'Alī, "Milkiyyāt," 972-1005; al-'Alī, "Muslim Estates," 255-26o and 249 on the lack of Anșārīs said to have benefitted during Muhammad's parceling out of the land of the expelled Banū l-Nadīir (on which, see also Lecker, Muslims, 123). Kister has noted that the Anșāīīs also failed to gain from the parceling out of the Banū Qurayzaa's land; see his "The Massacre of the Banū Qurayza: A Re-examination of a Tradition," Jerusalem Studies in Arabic and Islam 8 (1986): 95-96.

11 It is worth noting here that some scholars understood $m a \bar{l} l$, pl. amwāl, in a Medinan context as indicating specifically an "orchard" (bustān); for example, Ibn Ḥajar al-'Asqalānī, Fath al-bārī sharh Șaḥịh al-Bukhārī, new ed., eds. 'Abd al-'Azīz ibn Bāz and Muhammad Fu'ād 'Abd al-Bāqī (Beirut: Dār al-kutub al-'ilmiyya, 1410/1989), 11:40 (Kitāb al-istidhān, bāb 16).

12 Ibn Sa'd, Kitāb al-țabaqāt al-kubrā (Beirut: Dār șādir, 138o-1388/196o-1968), 3:126.

13 Wakī', Akhbār al-quḍāt, ed. 'Abd al-'Azīz al-Marāghī (Cairo: Maṭba'at al-istiqāma, 13661369/1947-1950), 1:138. There were, of course, other, non-Qurashī or Anșāin land owners in the Hijāz, but they seem to be encountered less frequently in the sources; for some Sulamī agricultural properties, see Michael Lecker, The Banū Sulaym: A Contribution to the Study of Early Islam (Jerusalem: The Hebrew University of Jerusalem, 1989), 221-228.

14 For a discussion of many issues surrounding Medina's haram, see Harry Munt, The Holy City of Medina: Sacred Space in Early Islamic Arabia (Cambridge: Cambridge University Press, 2014). 
of estates within this area, however, it seems that these restrictions on plants in and around Medina did not pose a serious hindrance to agriculture in the area, even if they were widely accepted in the Umayyad period (and this itself is far from clear). ${ }^{15}$

Water supply has always been a problem for cultivation throughout the Hijāz, and the lack of rain has ensured that any cultivated land has been in areas with sufficient groundwater. Al-'Ali has noted that most of the cultivable estates were located along the important $w \bar{a} d \bar{\imath}$ s, which either approached the town from the south (Buț̣ān) or passed it by to the west (al-Aqīq) and north (Qanāt). ${ }^{16}$ One traveler and geographer, al-Iștakhrī (wr. ca. second quarter of fourth/tenth century), notes a number of estates in the vicinity of Uhud to the north of Medina, many of which were in ruins by his day; ${ }^{17}$ these were presumably located along the Wādī Qanāt. The south of Medina, known as al-Āliya or al-Awālī because it is slightly higher than the area to the north (known as alSāfila), through which the Wādī Buṭhān ran, appears to have had particularly good cultivable land in pre- and early Islamic times; still in the 196os the village called 'Awâlī had the largest cultivated area in the region..$^{18}$ At least some of the Umayyad caliph Mu'āwiya's (r. 40-6o/661-68o) estates were in the 'Āliya, in the territory of the Banū l-Hārith b. al-Khazraj, around the settlement of al-Sunh:̣; ${ }^{19}$ another was north of the town near the Wādī Qanāt. ${ }^{20}$

We read in several sources about estate owners excavating wells ( $\bar{a} b \bar{a} r$, sg. birr) and 'uyūn (sg. 'ayn), perhaps "flowing springs" but maybe also something

15 There is evidence that agricultural developments around Mecca in the Sufyanid period were more controversial; see for example Kister, "Some Reports," 84-91. At least one eschatological tradition is relevant here, cited in al-Tha'labì, al-Kashf wa-l-bayān (TafsïralTha ¿abì), ed. Abū Muḥammad ibn 'Āshūr (Beirut: Dār iḥyā’ al-turāth al-'arabī, 1422/2002), 8:271: "How would it be for you if subterranean conduits were dug in Mecca?" (kayf bi-kum idhā buïjat Makka kazāàim).

16 As we will see below, the Wādī l-Aqīq to the west of Medina appears to have been particularly important for cultivation, and many prominent families are said to have had properties there (see further al-'Alī, "Studies," 91). For a property in Qanāt belonging to Ṭalḥa b. 'Ubayd Allāh, see al-'Alī, "Muslim Estates," 259.

17 al-Ișțakhrī, Kitāb al-masālik wa-l-mamālik, ed. M.J. de Goeje (Leiden: Brill, 1870), 18.

18 See esp. Lecker, Muslims, 1-3; Hasson, "Contributions," 10-16. Al-Fīrūzābādī (d. 817/1415) was particularly gushing in his praise of the 'Āliya's agricultural opportunities; see his al-

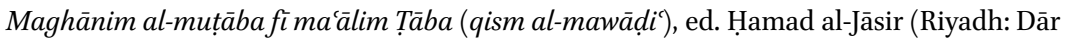
al-Yamāma, 1389/1969), 286.

19 al-Wāqidī in al-Samhūdī, Wafä̉ al-wafā, 1:250, and Abū l-Arab, Kitāb al-miḥan, 2nd ed., ed. Yaḥyā Wahīb al-Jabūrī (Beirut: Dār al-gharb al-islāmī, 1408/1988), 16o; Kister, "Battle," 38-39. For al-Sunh's location, see Lecker, Muslims, 6. 
similar to an underground channel bringing water from an aquifer $(q a n \bar{a} t) .{ }^{21}$ We also read more explicitly about such irrigation channels (sing. qanāt or khalïj) as well as dams (sing. sadd or dafira) being constructed. ${ }^{22}$ According to al-Wāqidī (d. 207/822), cited by al-Samhūdī and Abū l-Árab (d. 333/944945), one of Mu'āwiya's estate managers, Ibn Mīnā (see further on him below), may have undertaken the construction of a channel to bring water to his master's estates near al-Sunh. ${ }^{23}$ The most interesting pieces of evidence we have for dam building in the Hijāz are two inscriptions commemorating the completion of dams (both times the word for dam is sadd) ordered by the caliph Muâwiya. One of these is more than two hundred miles south of Medina, near al-Ṭāifi, and is dated to $58 / 677-678 ;{ }^{24}$ the other, which is undated but mentions Mu'āwiya by name, was found on one of two extant dams in the Wādī l-Khanaq, approximately six-to-ten miles southeast of Medina. ${ }^{25} \mathrm{~A}$ midto-late third-/ninth-century literary source also tells us that Mu'āwiya had a dam (sadd) constructed across the course of a wādi in one of the volcanic tracts (hirär, sg. harra) to the northeast of Medina. ${ }^{26}$

Mu'āwiya may not have been the first to have such dams constructed in the northern Hijāz: an archaeological survey of 1401/1981 investigated three dams in the region around Khaybar - about ninety miles north of Medina - and it

21 Several geographers noted the various methods of finding and using water in and around Medina; see, for example al-Ișțakhrī, Masālik, 18; al-Ya'qūbī, Kitāb al-buldān, ed. M.J. de Goeje (Leiden: Brill, 1892), 312-313.

22 'Urwa b. al-Zubayr (d. 94/712), for example, had dams and a famous well constructed on his estate in the 'Aqĩ (see further below). On the archaeological evidence for water transport and conservation across the Middle East, see Marcus Milwright, An Introduction to Islamic Archaeology (Edinburgh: Edinburgh University Press, 2010), 64-70.

23 Abū l-'Arab, Mihan, 159-16o; al-Samhūdī, Wafä’ al-wafā, 1:250; see also Ibn Qutayba (attrib.), Kitāb al-imāma wa-l-siyāsa (Cairo: Mațba'at al-Nīl, 1322/1904), 1:325. For a summary of all these accounts, see Kister, "Battle," 38-40. There is some confusion over what exactly Ibn Mīnā was doing in these reports. In many editions of these texts, Ibn Mīnā led a pasturing flock (sarh) to these estates. Kister amended this to sharj, which he understood as a "party [of workers]." The emendation to sharj appears to be correct, but it is interesting in this regard that another meaning of this word is "a place in which water flows from a stony tract such as is termed harra to a soft, or plain, tract" (Edward W. Lane, Arabic-English Lexicon (London: Williams and Norgate, 1863-1893), 4:152; s.v. 'sh-r-j'). Since Medina was surrounded on most sides by harras, this may well be the correct interpretation in this context.

24 For the text, see Miles, "Early Islamic Inscriptions," 237.

25 Saad al-Rashid, Dirāsāt fì l-äthār al-islāmiyya al-mubakkira bi-l-Madīna al-munawwara (Riyadh: Mu’assasat al-Huzaymī, 1421/200o), 32-6o.

26 Lughda al-Ișfahānī, Bilād al-'arab, eds. Șāliḥ Aḥmad al-'Alī and Ḥamad al-Jāsir (Riyadh: Dār al-Yamāma, 1388/1968), 401. 
has been suggested tentatively that although two were early Islamic, one of them was possibly a pre-Islamic structure. ${ }^{27}$ That caliph did nonetheless display a marked interest in patronising their construction. We cannot always be sure what the primary purpose of these dams was. In many instances, a primary aim was presumably to prevent flash-flooding in the wädīs, but storing water for use in agriculture or pasturing would have been an obvious secondary benefit. ${ }^{28}$ The same literary source who tells us about Mu'àwiya's dam in the volcanic tract northeast of Medina mentions specifically that "water would be kept back by [the dam], to which people would then bring their flocks to drink." 29

The difficulties that Medina's cultivators faced in procuring enough water are illuminated in a report preserved by the Andalusī Ibn Ra's Ghanama (fl. 620/1223-1224), which states that when there was a flash flood one day in Medina the inhabitants hurried out to direct the water to their properties, but Mu'âwiya's mawālı̀ went out to divert as much of the water as possible to his estates; this led to a fight. ${ }^{30}$ Excavations at some sites in the Hijāz have uncovered some of the ways through which the region's inhabitants in the Umayyad and Abbasid periods tried to collect and store water. At al-Rabadha, approximately one hundred miles east of Medina, excavators found not only two reservoirs on the outskirts of the settlement, but also underground water tanks attached to some buildings within. ${ }^{31}$ These constructions were not intended to provide water for the cultivation of land, but they demonstrate the lengths local residents had to go to in order to find and keep water. Further away at Fayd, two hundred and fifty miles northeast of Medina in Najd and a site occupied since at least the late second/eighth century, a number of water retention and utilisation structures have been found, including wells, dams, reservoirs and qanāts. ${ }^{32}$ Al-Rabadha is also an interesting example of the limits of cultivation in the region around Medina. Although it can get very green there when it does rain, there appears to have been relatively little agricultural activity in this particular part of the Hijāz; instead the area around this settlement was set aside for much

27 Michael Gilmore, Mohammed Al-Ibrahim and Abduljawwad S. Murad, "Preliminary Report on the Northwestern and Northern Region Survey 1981 (1401)," Ațlāl 6 (1982): 20.

28 See also Miles, "Early Islamic Inscriptions," 236; Milwright, Introduction, 64.

29 Lughda al-Iṣfahānī, Bilād al-'arab, 401.

$30 \quad$ Discussed by Kister, "Battle," $45-46$.

31 Saad al-Rashid, al-Rabadhah: A Portrait of Early Islamic Civilisation in Saudi Arabia (Riyadh: King Saud University, 1986), 41-48.

32 Fahd bin Saleh Al-Hawas, et al., "Preliminary Report on the Excavations of the Islamic Site of Faid, Hail Region, First Season, 1427 A.H./2006 A.D.," Ațlāl 20 (2010): 44-45, 49-5o, 5354 . 
of the Umayyad and early Abbasid period as a protected grazing land (hima a), and the most important vegetation associated with the site was connected to pasturage. $^{33}$

Our sources give us very little information about what was produced on the cultivated estates, but what data there is suggest that it was mostly dates, although other fruits and wheat were probably grown where possible. ${ }^{34} \mathrm{Al}-\mathrm{A}$ Ali has used the fact that Mālikī legal texts mention various types of grains, vegetables, oils, perfumes, and fruits to suggest that these were cultivated in Medina, at least by the time of Mālik b. Anas (d. 179/795), but this may be making too much of the information on offer: after all, most extant Mālikī legal texts were not actually written or transmitted primarily in the Hijāz. ${ }^{35}$ The geographer al-Muqaddasì (wr. late fourth/tenth century) noted that in his day among the special products (khașāis ) of Arabia were the bān trees and șayhănī dates of Medina. ${ }^{36}$ Apparently qaraz, a plant used in tanning, was grown in the Wādī l'Aqiq. ${ }^{37}$ It is probable that the vast majority of the produce from the estates was sold locally (or at least within the Hijāz)..$^{38}$ Dates, which seem to be Medina's most notable agricultural produce, are grown over much of the Middle East. ${ }^{39}$ Since Medina was a sizeable importer of many of the foodstuffs it supposedly produced, especially from Egypt to the nearby port of al-Jār on the Red Sea, ${ }^{40}$

al-Rashid, Rabadhah, 4. On the himā, see al-Samhūdī, Wafā’ al-wafā, 4:83-85.

34 Other products which may have been cultivated around Medina include bananas, pomegranates, and peaches; see al-'Alī, "Milkiyyāt," 968; Andrew M. Watson, Agricultural Innovation in the Early Islamic World: The Diffusion of Crops and Farming Techniques, 700-1100 (Cambridge: Cambridge University Press, 1983), 51-54. That dates and wheat were cultivated in the Hijāz will become clear from the following discussion, but for another example of wheat cultivation see Lecker, "Biographical Notes," 53.

35 al-'Alī, "Milkiyyāt," 968.

36 al-Muqaddasī, Ahsan al-taqāsìm fì márifat al-aqālīm, znd ed., ed. M.J. de Goeje (Leiden: Brill, 1906), 98. For seeds of the $b \bar{a} n$ tree as a Medinan export, see also Ibn al-Faqīh (wr. ca. 289-290/902-903), Mukhtașar Kitāb al-Buldān, ed. M.J. de Goeje (Leiden: Brill, 1885), 25. The oil of the $b \bar{a} n$ tree was apparently aromatic, and its seed had medicinal uses; see Lane, Arabic-English Lexicon, 1:278 (s.v. ' $b$-w-n').

37 Ahmad Khan, "The Tanning Cottage Industry in Pre-Islamic Arabia," Journal of the Pakistan Historical Society 19 (1971): 92.

38 There is some interesting information regarding the pre-Islamic period about some of the agricultural produce of Hijāzī settlements being used to pay surrounding tribes for protection and safe conduct; see Michael Lecker, "Were the Jewish Tribes in Arabia Clients of Arab Tribes?" in Patronate and Patronage in Early and Classical Islam, eds. Monique Bernards and John Nawas (Leiden: Brill, 2005), 59-66.

39 For example, Eliyahu Ashtor, A Social and Economic History of the Near East in the Middle Ages (London: Collins, 1976), 43-44.

There are plenty of references in the literary sources to Medina importing grain from Egypt 
but also from Syria via sea and land routes ${ }^{41}$ it is hard to imagine that it also exported very much of its local agricultural produce. Perhaps significantly, during the reign of Yazīd b. Mu'āwiya (r. 6o-64/68o-683) the price of wheat in Medina is said to have been higher than in Syria. ${ }^{42}$

Whatever the market was - and the internal market in the Hijāz may well have been enough to create a significant demand for these foodstuffs, especially during the hajj season when pilgrims to Mecca would have been passing through - the sources provide some impressive figures for the yields of produce from the estates around Medina, and for the profits that could be made from selling it. ${ }^{43} \mathrm{Ibn} \mathrm{Sadd} \mathrm{(d.} \mathrm{230/845),} \mathrm{for} \mathrm{example,} \mathrm{reports} \mathrm{that} \mathrm{while} \mathrm{Marwān}$ b. al-Hakam (d. 65/685) was in charge of the estate at Fadak (see further below) during the caliphate of Mu'āwiya, its produce sold for ten thousand dinars every year. ${ }^{44} \mathrm{Al}-W a \bar{q}$ idī claimed that Mu'āwiya's estates in Medina and its surrounding districts ( $a^{\prime} r a \bar{d} d$, sg. 'ird, a term used particularly for the administrative dependencies of Medina ${ }^{45}$ ) produced 150,000 wasqs of dates and 100,000 wasqs of wheat each year. ${ }^{46}$ Now such figures may be too high, but there is

via the ports of Clysma (al-Qulzum) and al-Jār; see further Philip Mayerson, "The Port of Clysma (Suez) in Transition from Roman to Arab Rule," Journal of Near Eastern Studies 55 (1996): 125-126; Clive Foss, "Egypt under Mucāwiya," Bulletin of the School of Oriental and African Studies 72 (2009): 20; Petra Sijpesteijn, Shaping a Muslim State: The World of a Mid-Eighth-Century Egyptian Official (Oxford: Oxford University Press, 2013), 76-77. There is also some papyrological evidence for grain ships leaving Clysma ( $C P R$ XXII 44, perhaps late seventh or early eighth century CE), but this papyrus does not record their destination. P.Lond. IV 1346 - dated to $710 \mathrm{CE}$ - also refers to grain shipments moving from Fusțât to Clysma, but without indication of their final destination. Al-Muqaddasī, Ahssan al-taqāsim, 97, however, did note that in his day (i.e. late fourth/tenth century) al-Jār and Jedda were "the two storage houses of Egypt" (khizānatay Mișr).

Alan Walmsley, "Production, Exchange and Regional Trade in the Islamic East Mediterranean: Old Structures, New Systems?" in The Long Eighth Century, eds. Inge Hansen and Chris Wickham (Leiden: Brill, 200o), 328; al-Muqaddasī (Aḥsan al-taqāsìm, 178) also called the southern Syrian port of Ayla "the storehouse of the Hijāz" (khizānat al-Hijāz). Pre- and very early Islamic Hijāā̄̄s - including 'Abd al-Raḥmān b. 'Awf and 'Abd Allāh b. Jud'ān (fl. late sixth century CE) - were thought to have imported wheat from Syria, and in the same period traders from Syria are said to have come to Medina to sell grain; see Patricia Crone, Meccan Trade and the Rise of Islam (Oxford: Blackwell, 1987), 98, 104, 139-140.

42 Ibn Qutayba, al-Imāma, 1:326; Kister, "Battle," 47-48.

43 See esp. the figures listed in al-'Alī, "Muslim Estates," 254-255. Lecker ("Jewish Tribes," 66) suggests that Medina and other Hijāzī settlements in the pre- and early Islamic period had "a huge surplus of dates."

44 Ibn Sa'd, Țabaqāt, 5:388.

45 Abdullah Al-Wohaibi, The Northern Hijaz in the Writings of the Arab Geographers, 800-1150 (Beirut: al-Risalah, 1973), 431.

46 Within Abū l-'Arab, Miḥan, 159; al-Samhūdī, Wafā̄ al-wafā, 1:25o; cf. al-'Alī, "Muslim 
some evidence to corroborate the picture that estates in the northern Hijāz could generate significant income: the well-known scholar Ibn Shihāb al-Zuhrī (d. 124/742) apparently made enough money from his land in the northern Hijāz to pay off the considerable debts he incurred through other activities. ${ }^{47}$ Nonetheless, it has been noted that many other estate owners in the region appear in the sources in straitened financial circumstances (although little further evidence is given of how this came to be). ${ }^{48}$

At any rate, it is important to note that scholars by the third/ninth century did not see anything strange in the possibility that considerable sums of money could be made from estates in and around Medina. Enterprising individuals could perhaps make money there. We still should not, however, envisage land around Medina as being nearly as valuable as that in some other regions of the caliphate; it is surely not for nothing that 'Uthmān b. 'Affān (r. 23-35/633-656) is said to have offered a land-swap program whereby Medinans who had participated in the conquests could exchange their land in Arabia for land in Iraq. ${ }^{49}$ Talḥa b. 'Ubayd Allāh was said to have made one thousand dirhams (per day?) from his estates in Iraq and ten thousand dinars (per year?) from his properties in Syria. ${ }^{50}$

It should be noted that this discussion concerns only agricultural produce from estates. Several properties around Medina are also said to have possessed precious metal mines, and these could have made much more money for estate owners if they were indeed in operation in the period under discussion..$^{51}$ On a

Estates," 251. In early Islamic times, one wasq was the equivalent of 252.3456 litres, or 194.3 kilograms; see Walther Hinz, Islamische Masse und Gewichte umgerechnet ins metrische System (Leiden: Brill, 1955), 53 .

47 Lecker, "Biographical Notes," 51.

48 al-'Alī, "Muslim Estates," 26o.

49 al-Ṭabarī, Ta’rīkh al-rusul wa-l-mulūk, eds. M.J. de Goeje et al. as: Annales quos scripsit Abu Djafar Mohammed ibn Djarir at-Tabari (Leiden: Brill 1879-1901), 1:2854-2856; see further Albrecht Noth, "Eine Standortbestimmung der Expansion (Futūh) unter den ersten Kalifen (Analyse von Țabarī I, 2854-2856)," Asiatische Studien 43 (1989): 120-136. The sources do not seem to record the precise ratio at which Hijāzī land could be swapped for Iraqi land. On the vastly more significant prosperity of agricultural land in the Sawād in southern Iraq, see Hugh Kennedy, "The Feeding of the Five Hundred Thousand: Cities and Agriculture in Early Islamic Mesopotamia," Iraq 73 (2011): 177-199.

50 William G. Millward, "The Adaptation of Men to Their Time: An Historical Essay by alYa'qūbī," Journal of the American Oriental Society 84 (1964): 335. Ten thousand dinars per year as the income of an estate comes across as something of a topos from the literary sources of the third/ninth century.

$5^{1} \quad$ Gene W. Heck, "Gold Mining in Arabia and the Rise of the Islamic State," Journal of the Economic and Social History of the Orient 42 (1999): 364-395. 
smaller scale, there was also a demand for steatite in Syria as well as in central and eastern Arabia, which could have been met from Hijāzī sources. ${ }^{52}$

As for who put in the hard work to generate all this produce, we very often simply do not know. Small property owners perhaps worked their own land, ${ }^{53}$ but the larger property owners with whom I am concerned here clearly would not have run their estates by themselves. In any case, many of them - including, of course, the caliphs - were absentee owners. ${ }^{54}$ Since the sources do not volunteer much information on this question, we have relatively little idea which of the various methods of organizing labor in other areas of the late antique and early medieval world - tenancy agreements of various kinds, wage labor, and slave labor ${ }^{55}$ - were used by Hijāzī landowners, although since it has been suggested that sharecropping was fairly common across the Islamic world that may have played a significant role in and around Medina. ${ }^{56}$

Slave labor also seems to have played some part. There are a few references to prisoners of war taken captive during the conquests of the mid-to-late first/seventh century being sent to the Hijāz to work on properties there. ${ }^{57}$ In one regularly recounted story, the caliph 'Uthmān b. 'Affān's son, Sa'ìd (d. after 56/675$676)$, took hostages from Samarqand in return for that city's good behavior.

52 For Syrian demand, see Walmsley, "Production," 331-332. Fayd is a good example of a central Arabian early Islamic site at which a large number of steatite objects were found: al-Hawas et al., "Preliminary Report," 73. As for the possible Hijāzī sources, the excavators at al-Rabadha located a steatite source roughly seven miles west of their site; see al-Rashid, Rabadhah, 77 .

53 al-'Alī, "Muslim Estates," 253; for elsewhere in the Islamic world, see Ashtor, Social and Economic History, 38.

54 Chris Wickham has suggested (Framing, 241) that the Umayyad family themselves were responsible for a "certain revival of long-distance landowning" in the Near East, since they owned properties all over the region.

55 On these alternatives see, for example, Ashtor, Social and Economic History, 37; Wickham, Framing, 272-280; John F. Haldon, Byzantium in the Seventh Century: The Transformation of a Culture, 2nd ed. (Cambridge: Cambridge University Press, 1997), 132-141; Jairus Banaji, "Aristocracies, Peasantries and the Framing of the Early Middle Ages," Journal of Agrarian Change 9 (2009): 59-91; Banaji, Agrarian Change, 19o-212. For forced laborers being used to work on the maintenance of irrigation canals in Egyptian papyri from Mu'āwiya's reign (P.Apoll. 26, 27), see Foss, "Egypt under Mu'āwiya," 16; Sijpesteijn, Shaping a Muslim State, 173, n. 309 .

56 For example, Claude Cahen, "Day'a," in Encyclopaedia of Islam, 2nd ed. (Leiden: Brill), http://dx.doi.org/10.1163/1573-3912_islam_SIM_1763; Ziaul Haque, Landlord and Peasant in Early Islam: A Study of the LegalDoctrine of Muzāra'a or Sharecropping (Islamabad: Islamic Research Institute, 1977); Banaji, "Aristocracies," 82. That various tenancy agreements may have been important in Umayyad Medina, see 'Abd al-'Azīz al-Dūrī, "Landlord and Peasant in Early Islam: A Critical Study," Der Islam 56 (1979): 105; al-'Alī, "Muslim Estates," 253.

See also al-'Alī, "Milkiyyāt," 967-968; al-'Alī, "Muslim Estates," 252-253. 
Breaking his agreement with the city, he then sent them on to Medina to work the land there. ${ }^{58}$ Kister also recounts further traditions which speak of forced and slave labor exploiting prisoners of war among others in the Hijāz in Mu'âwiya's time, ${ }^{59}$ and at least one fourth-/tenth-century geographer noted the presence of slaves ('abid) working on Medina's estates. ${ }^{60}$ We do know that the Muslim armies of the first/seventh and second/eighth centuries tended to take large numbers of prisoners when they raided territories; in one rather spectacular example, narrative sources' accounts of many prisoners taken during two raids on Cyprus in the late 20s/640s and early $30 \mathrm{Os} / 65$ os are corroborated by two extant Greek inscriptions found on the island in $1974 .{ }^{61}$ Anastasius of Sinai (d. ca. 700 CE) offers a relatively substantial amount of information about these prisoners' futures and notes that some of them ended up working in terrible conditions on estates near the Dead Sea. ${ }^{62}$

It is possible that slaves taken from East Africa may also have worked on the estates in and around Medina. ${ }^{63}$ We hear almost nothing about these slaves in the sources, but in the early Abbasid period, in $145 / 762-763$, they revolted in Medina. The most important source for this revolt, al-Tabarī (d. 310/923), mentions that those who rebelled were slaves ('abid), but gives little further indication as to what work they performed. ${ }^{64}$ The most notable point to come out of al- Tabarin's account is that these slaves do not seem to have revolted

$5^{8}$ al-Ya'qūbī, Ta’̀īkh, ed. T. Houtsma as: Ibn-Wādhih qui dicitur al-Ja'qubī Historiae (Leiden: Brill, 1883), 2:282; al-Balādhurī, Kitāb Futūḥ al-buldān, ed. M.J. de Goeje as: Liber expugnationis regionum (Leiden: Brill, 1866), 411-412; al-Ṭabarī, Ta’rīkh, 2:179; Mușsab ibn 'Abd Allāh al-Zubayrī, Kitāb Nasab Quraysh, 4th ed., ed. E. Levi-Provençal (Cairo: Dār al-macārif, n.d.), 111.

59 Kister, "Battle," 44-47. See also Lecker, "Biographical Notes," 52.

6o al-Iștakhrī, Masālik, 18.

61 al-Balādhurī, Futūh, 152-153; Robert G. Hoyland, Theophilus of Edessa's Chronicle and the Circulation of Historical Knowledge in Late Antiquity and Early Islam (Liverpool: Liverpool University Press, 2011), 131-134; Denis Feissel, "Jean de Soloi, un évêque chypriote au milieu du viI ${ }^{\mathrm{e}}$ siècle," Travaux et mémoire 17 (2013): 227-234. For an interesting discussion of the status of Cyprus's inhabitants within emerging Islamic legal thought, see now Ryan J. Lynch, "Cyprus and Its Legal and Historiographical Significance in Early Islamic History," Journal of the American Oriental Society 136 (2016): 535-550.

62 Bernard Flusin, "Démons et sarrasins: l' auteur et le propos des Diègèmata stèriktika d'Anastase le Sinaïte," Travaux et mémoire 11 (1991): 400-404; Robert G. Hoyland, Seeing Islam as Others Saw It: A Survey and Evaluation of Christian, Jewish and Zoroastrian Writings on Early Islam (Princeton: Darwin Press, 1997), 100.

63 See also Meir J. Kister, "The Social and Political Implications of Three Traditions in the Kitāb al-Kharādj of Yahya b. Adam," Journal of the Economic and Social History of the Orient3 (1960): 333-334.

64 al-Ṭabarī, Ta'rīkh, 3:265-271. 
against their owners, but rather against the Abbasid troops in the town. They may have been laborers on the estates in and around the town, but they may just as well have performed other tasks for their owners.

We do have a little interesting information about how absentee owners went about ensuring the smooth operation of their Medinan properties. Mu'āwiya appointed at least three officials to do the job for him. One of them was Ibn Mīnā, referred to as "the administrator of Mu'āwiya's estates" ('āmil ['alā] șawāfi Mu'āwiya; also 'alā șawāfì al-Madīna li-Mu'āwiya; for the use of șawāfi here, see further below); 65 the second was 'Abd al-Raḥmān b. Abī Aḥmad b. Jaḥsh, Mucāwiya's "agent in charge of his estates in Medina" (wa-kāna wakilahu bi-diyāihi bi-l-Madīna). ${ }^{66}$ The third is one otherwise unidentified al-Nadiir, "Mu'āwiya's agent in Medina" (wakīl Mu'āwiya bi-l-Madīna); it is clear that dealing with the caliph's agricultural estates was at least part of his remit. ${ }^{67}$ Mu'āwiya's dam inscription from Wādī l-Khanaq also mentions two people, Abū Mūsā and Kathīr b. al-Ṣalt, who oversaw its construction. ${ }^{68}$ It is virtually impossible to identify the first of these individuals from the kunya "Abū Mūsā" alone, but Kathīr b. al-Ṣalt can be found in other sources. ${ }^{69} \mathrm{He}$ also oversaw the construction of the minbar in the prayer ground (musallā) in Medina for the caliph 'Uthmān b. 'Affān (r. 23-35/644-656). ${ }^{70}$ Kathīr appears to have been either a caliphal official or an Umayyad family agent entrusted with sensitive operations Medina. ${ }^{71}$

65 al-Ya‘qūbī. Ta’rīkh, 2:297; Abū l-'Arab, Miḥan, 159; al-Samhūdī, Wafā’ al-wafā, 1:25o (citing al-Wāqidī's Kitāb al-ḥarra); erroneously spelt as Ibn Mìthā' in Ibn Qutayba, al-Imāma, 1:325.

66 al-Zubayr b. Bakkār (d. 256/870) within al-Samhūdī, Wafä̀ al-wafā, 4:405.

67 al-Balādhurī, Ansāb al-ashrāf, vol. 4, no. 1, ed. Iṇsān 'Abbās (Beirut: Franz Steiner, 140o/ 1979), 132-133 (citing al-Wāqidī).

68 al-Rashid, Dirāsāt, 46, 51-52.

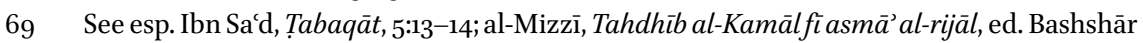
'Awwād Ma'rūf (Beirut: Mu’assasat al-Risāla, 1402-1413/1982-1992), 24:127-131. A Kindī, Kathīr emigrated to Medina and was known to have had a "residential court" (dār) in Medina, southwest of the mușallā, on which see al-'Alī, "Studies," 8o.

70 Ibn Shabba, Ta'rīkh al-Madina, 1:87-88.

71 He may have been a more general Umayyad official, since al-Mizzī (Tahdhïb al-Kamāl, 24:128) says that he was a chancery official for 'Abd al-Malik b. Marwān (r. 65-86/685-705). Agents in charge of estate acquisition and management on behalf of Umayyad caliphs and their governors also appear in sources for other regions. Hishām b. 'Abd al-Malik (r. 105-125/724-743) appointed one Ḥassān al-Nabați to manage his Basran properties; see alBalādhurī, Futūḥ, 368; al-Jahshiyārī, Kitāb al-Wuzarā’ wa-l-kuttāb, eds. Mușțafā al-Saqqā et al. (Cairo: Mușțafā al-Bābī al-Halabī, 1357/1938), 61-62. Al-Jahshiyārī also informs us that Isḥāq b. Qabīṣa oversaw Hishām's estates (divy $\bar{a}^{c}$ ) in Jordan, as well as being in charge of 
The narrative accounts we get of Ibn Mīnās role in Medina, always in the context of events leading up to the Battle of the Harra, give a very basic indication of how Mu'āwiya's and Yazīd b. Mu'āwiya's estates in Medina were operated. According to al-Ya'qūbī (d. ca. 292/904-905), Ibn Mīnā usually collected the crops of wheat and dates every year. ${ }^{72}$ If this report is accurate, then it would seem that Ibn Minā took a personal interest in the management of these estates around Medina, and that his Umayyad masters were interested in the direct collection of the agricultural produce of those estates rather than simply extracting rents from tenants. This in turn suggests that there was a secure market for those products, presumably local.

Finally, there is the matter of how estate owners, especially the Umayyad caliphs and their relatives, might have acquired their land. Bringing new land under cultivation was a popular way of acquiring land in other provinces of the caliphate in the early Islamic period, ${ }^{73}$ and it appears to have been an important factor driving estate acquisition around Medina too. Mu'āwiya, for example, is frequently reported to have sought ways of bringing water to new lands, and constructed wells, dams, and canals to facilitate this; ${ }^{74}$ the caliph Hishām b. 'Abd al-Malik's (r. 105-125/724-743) maternal uncle and governor of Medina, Ibrāhīm b. Hishām b. Ismāīl (d. 126/743), also excavated a spring. ${ }^{75}$ These activities in Medina are comparable to the better known examples of Umayyad family members' and their officials' amelioration of lands elsewhere in the caliphate, including the Syrian-Jordanian desert fringe as well as the Tigris and Euphrates valleys in the Jazīra. ${ }^{76}$ It is not always clear for this period whether

the caliph's dīwān al-ṣadaqa in general, but since Isḥāq was Hishām's governor of Jordan he surely delegated that job; see al-Jahshiyārī, Wuzarā', 6o; and on Ishāq b. Qabīṣa more generally, see Ibn 'Asākir, Ta’rīkh madīnat Dimashq, eds. 'Alī Shīrī and 'Umar al-'Amrawī (Beirut: Dār al-fikr, 1415-1421/1995-200o), 8:270-272.

72 al-Ya'qūbī, Tàrīkh, 2:297-298 (see also 278).

73 Ashtor, Social and Economic History, 6o-63; al-Dūrī, "Landlord and Peasant," 101-102; Uzi Avner and Jodi Magness, "Early Islamic Settlement in the Southern Negev," Bulletin of the American Schools of Oriental Research 310 (1998): 46-49; Banaji, "Late Antique Legacies," 169-17o.

74 Mu'āwiya's dams near Medina were discussed above. On his excavation of wells, see for example al-Samhūdī, Wafă’ al-wafā, 1:364, 3:194, 330, 332, 397, 4:402.

75 al-Samhūdī, 4:397, 478 .

76 The best studied examples are the Umayyad qușūr in Syria, on which see, for example, Jere L. Bacharach, "Marwanid Umayyad Building Activities: Speculations on Patronage," Muqarnas 13 (1996): 27-44; Garth Fowden, Qușayr 'Amra: Art and the Umayyad Elite in Late Antique Syria (Berkeley: University of California Press, 2004); Denis Genequand, "Formation et devenir du paysage architectural omeyyade: l' apport de l' archéologie," in Umayyad 
land owners usually had to buy this land first, before bringing it under cultivation. Sometimes they certainly appear to have done so. 'Urwa b. al-Zubayr (d. 94/712), for example, who famously constructed a well, dams, and irrigation channels over his lands in the Wādī l-'Aqīq, southwest of Medina, apparently had to buy the property first from 'Abd Allāh b. 'Ayyāsh (d. 78/697-698).77

As well as bringing new land under cultivation, caliphs and their governors could, of course, confiscate others' estates. There are several examples of this happening in Medina during the Umayyad period and many more of its occurrence elsewhere. I mentioned already that one Anșāin who did own lands in Medina, Abū Bakr b. Muhammad b. 'Amr b. Hazm, saw them confiscated by al-Walīd b. 'Abd al-Malik (r. 86-96/705-715). ${ }^{78}$ The case of Fadak, an estate frequently confiscated from and restored to its supposedly rightful owners, was also widely discussed by Muslim scholars (see further below). All these Umayyad lands around Medina - and elsewhere in the caliphate - were no doubt in turn confiscated by the Abbasids after their seizure of power in the mid-second/eighth century. ${ }^{79}$

In spite of the use of confiscations and appropriations, Umayyad family members also frequently purchased properties in and around Medina. As is often the case, the evidence is most plentiful for Mu āwiya's activities. ${ }^{80}$ Caliphs and their representatives, however, do not always appear to have bought their properties fairly. "Distress sales," where caliphs profited from purchasing estates from those in debt, may have been relatively common..$^{81}$ For a particularly good example of this, it is worth citing the reported complaint of a group of Medinans (comprising both Qurashīs and Anșārīs) made to the

Legacies: Medieval Memories from Syria to Spain, eds. Antoine Borrut and Paul M. Cobb (Leiden: Brill, 2010), 437-444; Antoine Borrut, Entre mémoire et pouvoir: l'espace syrien sous les derniers Omeyyades et les premiers Abbassides (Leiden: Brill, 2011), 412-435. For the Jazīra, see Chase F. Robinson, Empire and Elites after the Muslim Conquest: The Transformation of Northern Mesopotamia (Cambridge: Cambridge University Press, 2000), 78-80. Hishām b. 'Abd al-Malik was famous for building irrigation works and bringing lands under cultivation, and the sums he spent on this apparently made him quite unpopular in some quarters; for example, Khalid Yahya Blankinship, The End of the Jihad State: The Reign of Hisham ibn 'Abd al-Malik and the Collapse of the Umayyads (Albany, NY: State University of New York Press, 1994), 91.

77 al-Samhūdī, Wafă’al-wafā, 4:16-17.

78 Wakī', Akhbār al-quḍāt, 1:138. For another example involving Mu'āwiya and his agent alNaḍīr, see al-Balādhurī, Ansāb, 132-133.

79 On early Abbasid seizure of lands in the Hijāz, see Arazi, "Matériaux," 201-212.

8o al-Fīrūzābādī, al-Maghānim, 253-256; al-Samhūdī, Wafă’ al-wafā, 2:204, 3:21-23, 74, 95, 367-369, 4:31-35, 47, 165, 405.

81 See also the discussion in Banaji, "Late Antique Legacies," 169-170. 
governor 'Uthmān b. Muhammad b. Abī Sufyān in the run up to the Battle of the Harra in $63 / 683^{82}$

You know that these properties all belong to us, but that Mu'āwiya preferred [others] over us when [handing out] our stipends ('ața'), not even giving us a dirham, let alone anything more. So the time arrived when hunger afflicted us and he bought them from us for one-hundredth of their value.

This emphasis on "distress sales" was perhaps a topos (Mu'āwiya's sometimes impious shrewdness certainly was), the intention of which was to disparage the practices of earlier Umayyad caliphs in Abbasid times. Nonetheless, as Nicola Clarke has nicely put it, "a topos can be a topos and still have a basis in events," and so there may be something to the picture of Umayyads capitalising on the desperation of landholders in straightened circumstances. ${ }^{83}$

It is worth noting here that these lands held by the Umayyad family around Medina, even those owned by caliphs and their governors, appear to have been private properties rather than state lands, although in this early stage, of course, there may not have been much of a distinction between the two categories. ${ }^{84}$ With this in mind, it should be highlighted that even though some sources refer to Mu'āwiya's lands in the Hijāz as șawāf employed, at least in reference to southern Iraq, to former Sasanian lands taken over by the Muslim state and theoretically administered by the caliphs on behalf of the Muslim community - it is still clear that they were his private properties. ${ }^{85}$ As Kister noted, where some sources call these estates șawäfi, oth-

82 Ibn Qutayba, al-Imāma, 1:325; also Kister, "Battle," 47.

83 Nicola Clarke, The Muslim Conquest of Iberia: Medieval Arabic Narratives (London: Routledge, 2012), 2.

84 Blankinship (End of the Jihad State, 85) has suggested that it may only have been under 'Umar b. 'Abd al-'Azīz and Hishām b. 'Abd al-Malik that the first serious steps were taken to separate state finances from the caliph's private wealth. On the other hand, such a separation may never have occurred fully in the Umayyad period, since rebels continue to complain right to the end of their rule about that family's misappropriation of what they saw as the property and revenue of the Muslim community; see, for example, Abū Ḥamza al-Khārijī's sermon, which was delivered in either Mecca or Medina in either 129 or 130/747, in Patricia Crone and Martin Hinds, God's Caliph: Religious Authority in the First Centuries of Islam (Cambridge: Cambridge University Press, 1986), 129132.

85 For a general discussion, see Ann K.S. Lambton, “Ṣafî (pl. safāyā), Șawāfî,” in Encyclopaedia of Islam, 2nd ed. (Leiden: Brill), http://dx.doi.org/10.1163/1573-3912_islam_SIM_6444. 
ers simply call them amwāl, "private property," ${ }^{\text {"6 }}$ and al-Ya'qūbī explicitly states that Mu'āwiya personally owned șawāfit. ${ }^{87}$ Jairus Banaji has since also added the observation that since Medina would have had no pre-Islamic tradition of crown or state property, șawāf $\iota$ almost certainly there refer to Mu'āwiya's personal estates. 88

It would appear, therefore, that in spite of the stigma attached by some circles to the cultivation of the land, ${ }^{89}$ and the relatively meagre profits to be made by doing so in the Hijāz compared to the potential for higher earnings in Syria, the Jazira, Egypt and Iraq, the Umayyads - led by the caliphs from their family - sought from the reign of Mu'āwiya onwards to acquire large properties for themselves in and around Medina. This is all the more interesting when we consider that they may not have done so until slightly later in Egypt, a much more promising area for profitable exploitation. ${ }^{90}$

\section{For Profit or Control?}

Members of the Umayyad family in the Marwanid era do not appear quite so frequently in the sources appropriating, buying, or cultivating land in and around Medina as Mu'āwiya, but they certainly did from time to time seek to acquire properties in ways which brought them into conflict with other families in Medina. I have already mentioned 'Urwa b. al-Zubayr's estate in the Wādī

86 Compare, for example, al-Ya'qūbī, Ta’rīkh, 2:297, with Ibn Qutayba, al-Imāma, 1:325; Abū l-Arab, Miḥan, 16o; al-Samhūdī, Wafä' al-wafā, 1:250.

87 al-Ya'qūbī, Tảrīkh, 2:278: wa-kāna awwal man kānat la-hu l-șawāfífíjamì al-dunyā hattā biMakka wa-l-Madina. For further discussion, see esp. Kister, "Battle," 41-43. It was, of course, a fairly common complaint among rebels that the Umayyads misappropriated wealth and property rightly belonging to the Muslim community; see above, n. 84 .

88 Banaji, "Late Antique Legacies," 170.

89 On this, see esp. Meir J. Kister, "Land Property and Jihād: A Discussion of Some Early Traditions," Journal of the Economic and Social History of the Orient 34 (1991): 270-311.

90 On Muslims owning properties in Egypt, see Petra M. Sijpesteijn, "Landholding Patterns in Early Islamic Egypt," Journal of Agrarian Change 9 (2009): 123-124, 128. Apparently, the first papyrological evidence for an elite Muslim holding agricultural land in Egypt comes in a document ( $C P R$ VIII, 82) from the Fayyūm dating to 699-700 CE, which mentions a vineyard belonging to the caliph (amir al-mu'minin). Of course, the caliphs' reluctance to encourage direct Muslim landholding in Egypt may have been due, as Sijpesteijn suggests, to the fact that it was easier for elites to make money from taxing land directly in the conquered provinces; since, according to the legal theory at least, land in the Hijāz only paid the lower 'ushr rate of taxation, such considerations are less likely to have been applied there. For the legal theory on the tax status of Hijāzī land, see Abū Yūsuf, Kitāb al-kharāj (Cairo: al-Mațba'a al-mīriyya, 1302/1884-1885), 33-35, 39, 69. 
l-Aqīq to the southwest of Medina in this paper.91 'Umar b. al-Khatțāb (r. 1323/634-644) apparently granted (aqtáca) this land to an Anșāin called Khawwāt b. Jubayr (d. 4o/66o-661), but Marwān b. al-Hakam took it from him during the reign of Mu'āwiya and granted it instead to the aforementioned 'Abd Allāh b. 'Ayyāsh, from whom 'Urwa later purchased it. 'Urwa then started building dams (dafä'ir), canals, and wells on the lands. ${ }^{92}$ During al-Walīd b. 'Abd al-Malik's reign, 'Urwa entered into a dispute with the owner of the neighboring land, the Umayyad 'Abd Allāh b. 'Amr b. 'Uthmān b. 'Affān (d. 96/714-715). 'Abd Allāh complained to 'Umar b. 'Abd al-'Azīz, the governor of Medina (in office ca. 8693/705-712), and the latter had 'Urwa's new building works destroyed. What is interesting is what 'Abd Allāh said to 'Umar to get him to act on his behalf. According to one report, after alleging that 'Urwa had built and dug where he had no right to do so, 'Abd Allāh apparently told 'Umar:"93

Riders used to alight at Marwān [b. al- Ḥakam's] well, but when 'Urwa excavated his well and found that the water was sweet they chose the easy route and the sweet water and ceased stopping at Marwān's well. 'Umar was already upset about that, and in any case disliked the Banū l-Zubayr in general (wa-kāna fì nafs 'Umar ibn 'Abd al-Azìz shay' min dhālika ma'a mā kāna fì nafsihi áä jamī Banì l-Zubayr).

'Umar b. 'Abd al-'Azīz, who was Marwān b. al-Ḥakam's grandson, was worried about the threat 'Urwa's estate and infrastructure posed to Marwanid family interests. ${ }^{94}$ The caliph al-Walīd b. 'Abd al-Malik, however, sided against his relatives and interceded on 'Urwa's behalf; he was given permission to rebuild

91 On this estate, see esp. Yāqūt, Mújam al-buldān, ed. Ferdinand Wüstenfeld as: Jacut's geographisches Wörterbuch (Leipzig: F.A. Brockhaus, 1866-1873), 4:116-117; al-Fīrūzābādī, al-Maghānim, 342-345; al-Samhūdī, Wafă' al-wafā, 4:14-22. It is a little unclear who alSamhūdī's main source for this section was, but it was probably al-Zubayr b. Bakkār; other Zubayrid family authorities, including 'Urwa and Hishām b. 'Urwa (d. 146/763), are cited as further authorities.

92 'Urwa's estate in the 'Aqīq sounds relatively similar, albeit on a significantly smaller scale, to the remains at Umm al-Walīd, in the Balqä’ south of Amman, on which see Genequand, "Formation," 441-442. For a rather overambitious attempt to identify the possible remains of some of these structures, see Khālid b. Muhammad Askūbī, "Archaeological Survey of Western Al-Madinah al-Munawwarah, 1424A.H.-2004A.D. Season," Ațlāl 20 (1431/2010): 152-153.

93 al-Samhūdī, Wafä̀ al-wafā, 4:18.

94 Other reports in al-Samhūdī's account (for example, at IV, 17) also explicitly suggest that 'Abd Allāh b. 'Amr tried to suggest that 'Urwa's estate and works were a threat to the Umayyad family's interests in Medina. 
his well and construct a new qașr (in this context, perhaps "villa"). 'Urwa was so grateful that he appointed al-Walīd as the executor of his testament for his estate.

After 'Urwa's death, during the reign of Hishām b. 'Abd al-Malik (r. 105125/724-743), however, the governor of Medina, the aforementioned Ibrāhim b. Hishām, tried to force 'Urwa's sons Yahyā and 'Abd Allāh, who had inherited the estate after their father's death in 94/712, into granting him some rights to their land; Ibrāhīm had 'Urwa's qaṣr destroyed and a camel's corpse coated in $\operatorname{tar}$ (qatrān) thrown down the well. ${ }^{95}$ It is possible that this time also it was the threat posed by 'Urwa's well to that controlled by the Marwanids that caused the governor to act. As did his predecessor al-Walīd, however, Hishām intervened on the Zubayrids' behalf, against his own relatives, to have their full rights restored. 'Urwa's sons, Yahyā and 'Abd Allāh, were not the only Zubayrids whose property rights Ibrāhīm $b$. Hishām infringed upon: when the latter built a residential court $(d \bar{a} r)$ in the town, he encroached upon the rights of 'Āmir b. 'Abd Allāh b. al-Zubayr (d. ca. 125/742-743). ${ }^{96}$

As well as the Umayyads and the Zubayrids, the other largest propertyowning family in the region were the Alids and they appear frequently in disputes too. There was, for example, a clash between them and certain Umayyad family members over a property - one of 'Alī b. Abì Țālib’s șadaqāt, or "charitable endowments" - near Yanbu' called al-Bughaybigha/al-Bughaybighāt or al-Nu'aynica, although the exact details of this dispute are not clear. ${ }^{97}$ Much

95 It seems that this conflict started with a dispute over property in al-Fur'; see al-Samhūdī, Wafă al-wafā, IV, 20. On the location of al-Fur' in the Hijāz, and its economic importance and prominent landowners, see al-Wohaibi, Northern Hijaz, 69-71. For Yahyā's and 'Abd Allāh's uneasy relationship with Ibrāhīm b. Hishām, see also for example al-Zubayrī, Nasab Quraysh, 246-247; Ibn 'Asākir, Ta'rīkh madīnat Dimashq, 31:17-19.

96 al-Samhūīi, Wafä' al-wafā, 3:64-65; it is unclear who the ultimate source for this information is. I follow previous scholars in translating dār in this Medinan context as "residential court", although for what precisely the term represents, see, for example, Kister, "Massacre," 74, n. 39: dār "often denotes a compound building, sometimes of considerable dimensions, containing in certain cases stores, workshops, magazines and even markets."

97 For al-Bughaybigha, see Ibn Shabba, Tảrīkh al-Madīna, 1:136-138; al-Fīrūzābādī, al-Maghānim, 59-6o; al-Samhūdī, Wafă’ al-wafā, 4:164-166; al-Mubarrad, al-Kitāb al-kāmil, ed. William Wright (Leipzig: F.A. Brockhaus, 1874-1892), part 7, 555-558. For al-Nu'aynica, see Wakī', Akhbār al-qud̄āt, 1:152-154. The reason the details are not clear is that although it seems reasonably certain that al-Bughaybigha and al-Nu'ayni'a are the same place (in Arabic, the two words are distinguished only by diacritical marks), reports about the former provide at least two different ownership histories, and Wakī provides a third for the latter. On this estate, see also Asad Q. Ahmed, The Religious Elite of the Early Islamic Hijäz: Five 
more famous among Muslim scholars, however, was the controversy over the estate at Fadak. Fadak is an oasis in the northern Hijāz, two-to-three days journey north-east of Medina. ${ }^{98}$ It was said to have been captured by the Muslims following a raid during Muhammad's lifetime. According to one account of the controversy, Muhammad's daughter Fātima (ancestor of two very important Alid family lines) had asked her father to grant her Fadak, but he declined and instead dedicated the proceeds to the upkeep of the poor and needy travelers (ibn al-sabil)..${ }^{99}$ The first four caliphs apparently stuck to this, but then Mu'āwiya granted the land to Marwān b. al-Ḥakam, his governor of Medina. Marwān passed it on to his two sons, 'Abd al-'Azīz (d. 85/704) and 'Abd al-Malik, the future caliph. Then it passed jointly to al-Walīd b. 'Abd al-Malik, Sulaymān b. 'Abd al-Malik (r. 96-99/715-717), and 'Umar b. 'Abd al-'Azīz (r. 99-101/717-720). Al-Walīd and Sulaymān, at 'Umar's request, gave him their portions, and 'Umar then promised to restore the money from Fadak to the purpose ordered by the Prophet. ${ }^{100}$ After Yazīd b. 'Abd al-Malik (r. 101-105/720-724) had succeeded 'Umar as caliph, however, he confiscated Fadak again. ${ }^{101}$ We should be suspicious of many of the details in this account - especially the claim that 'Umar b. 'Abd al-'Aziz returned the estate to its original purpose before his successor Yazìd re-confiscated it - but the general picture of Umayyad confiscations of this estate, which the Alids considered as theirs whether or not its proceeds were to go towards their own profit or the benefit of poorer members of

Prosopographical Case Studies (Oxford: Unit for Prosopographical Research, 2011), 12813 .

98 Yāqūt, Mújam al-buldān, 3:855. It has been suggested that Fadak should be identified with the modern village al-Hāaiț, roughly one hundred and twenty miles northeast of Medina; see Ḥamad al-Jāsir, Fì shamāl gharb al-jazīra: nuṣūṣ, mushāhadāt, ințibā'āt (Riyadh: Dār al-Yamāma, 139o/1970), 295.

99 For a detailed discussion of the Fadak dispute see, for example, Ibn Shabba, Ta'rikh alMadīna, 1:120-124; al-Samhūdī, Wafă'al-wafā, 4:416-419. For a recent discussion of reports about Fāțima's claim regarding Fadak, see Tayeb El-Hibri, Parable and Politics in Early Islamic History: The Rashidun Caliphs (New York: Columbia University Press, 2010), 5961. At 59, El-Hibri interprets these narratives as "a symbolic device used by narrators to allude to Fāṭima's (and the Hāshimites') claim to inheriting the Prophet's legacy and leadership (both political and religious)." This may be so, but later literary use of the episode does not necessitate that there was not a real issue over the ownership of Fadak, especially in the Umayyad period. Cf. however, $35^{6-357}$, n. 78 of the same work, where El-Hibri does suggests that the Fadak narrative is an Abbasid invention.

100 Ibn Sacd, Ṭabaqāt, 5:388-389; al-Balādhurī, Futūh, 32.

101 al-Ya'qūbī, Ta’rīkh, 2:366; Yāqūt, Mứcam al-buldān, 3:856. For an overview of the controversies over the ownership of Fadak well into the Abbasid period, see L. Veccia Vaglieri, "Fadak," in Encyclopaedia of Islam, 2nd ed. (Leiden: Brill), http://dx.doi.org/10.1163/1573 -3912_islam_SIM_2218. 
society, seems reasonable. The șadaqūt of 'Alī were apparently also disputed within the wider Talibid family. ${ }^{102}$

There are plenty of other accounts of Umayyads involved in controversial land deals in and around Medina. 'Umar b. 'Abd al-'Azìz is said to have bought an estate from the descendants of Bilāl b. al-Ḥārith al-Muzanī (d. before 6o/68o) in which precious mineral resources were later discovered. Bilāl's descendants claimed that they had only sold 'Umar the rights to the cultivable land, not to any non-agricultural minerals that may later have been discovered there (innamā bi'nāka ard harth wa-lam nabika l-ma'ādin). According to al-Balādhurī (d. ca. 279/892-893), 'Umar apparently returned the proceeds of the minerals to Biläl's family willingly, but there may well originally have been more legal wrangling than this brief account suggests. ${ }^{103}$ The Umayyads also appear to have stopped others from exploiting new lands by banning building projects (and thus preventing essential irrigation works) in certain areas around the town including, according to Ibn Zabāla (d. after 199/814), al-'Arșa down to the reign of al-Walìd b. 'Abd al-Malik. ${ }^{104}$

Of all the information we read about Medinan estates, however, it is the accounts which report tensions between the Umayyads and the Zubayrids or Alids which are the most useful in seeking to understand why the caliphs were so concerned with acquiring and maintaining estates in and around Medina. These brief narratives suggest that the Umayyads were not interested in agricultural estates in the Hijāz solely because of the potential profits that could be made. They probably would not have bothered to acquire historically lossmaking land, but since there were much larger profits to be made in several other provinces where the Umayyads either did direct or might have chosen to direct their attentions, profit alone cannot necessarily explain their interest in acquiring Medinan estates. Rather, this interest stemmed primarily from a desire to prevent their principal rivals for the caliphate - who themselves remained most securely propertied in the Hijāa $\mathrm{z}^{105}$ - acquiring too much landed property of their own.

102 See, for example, Amikam Elad, "The Struggle for Legitimacy of Authority as Reflected in the Hadīth of al-Mahdī," in 'Abbasid Studies II: Occasional Papers of the School of 'Abbasid Studies, Leuven, 28June-1 July 2004, ed. John Nawas (Leuven: Peeters, 2010), 45-46, n. 33.

103 al-Balādhurī, Futūh, 13.

104 Within al-Samhūdī, Wafă’ al-wafā, 4:3o. Al-'Arṣa was a valuable agricultural area to the west of Medina, on which see al-Fīrūzābādī, al-Maghānim, 252-258; al-'Alī, "Studies," 9o.

105 Many other Medinan elite families, including the Alids and Zubayrids, did also seek estates outside of the Hijāz, particularly in southern Iraq; for a concise overview, see Millward, "Adaptation," 335. They did not do so, however, as enthusiastically as the Umayyads - pre- 
Medina was not, of course, any old town; its emergence as a holy city was taking gradual shape over the Umayyad period - in particular from the reign of al-Walīd b. 'Abd al-Malik onwards - and into the Abbasid era. ${ }^{106}$ This everwidening recognition of Medina's sanctity alongside Mecca's, and with it the wider Hijāz's emergence as an Islamic holy land, may have ensured that properties in and around Medina had a certain "sacred value" that encouraged land acquisition in the area. Francis E. Peters has suggested something similar for Mecca:

Properties around the haram may not have realized large monetary profits - merely keeping them in repair would have entailed a considerable expense - but they reaped, in the manner of holy places, an incalculable reward in visibility and prestige. ${ }^{107}$

It is actually quite hard, however, to use the notion of "sacred value" to account for the phenomena of large Umayyad estate ownership around Medina that we have been discussing here. For one thing, as I have just noted, it is only from the caliphate of al-Walīd b. 'Abd al-Malik - so after all of Mu'āwiya's activities - that the process of Medina's emergence as a holy city began to accelerate. The narratives of Mu'āwiya's estate acquisition activities in Medina do not give any indication that he placed an emphasis on the "sacred value" of his lands around the town; nor, for that matter, do the accounts of many later land disputes indicate that any such feelings were held by those participants. Some small properties may have been purchased by individuals with the intention of residing in madinat al-nabī, "the Prophet's City," but it seems to me that agricultural estates are unlikely to have been sought after for this reason alone.

There are also third-/ninth-century statements that some first-/seventhcentury Muslims happily gave up properties right next to the Prophet's Mosque in Medina in return for land elsewhere that was more valuable. According to al-Walīd b. Hishām al-Qaḥdhamī (d. 222/837):

sumably since, not controlling the caliphate and its official appointments, they had fewer opportunities - and the wealth of many Alids and Zubayrids over the second/eighth and third/ninth centuries remained firmly tied to properties in the northern Hijāz.

106 For a detailed study of Medina's emergence and development as a sacred space and a holy city, see Munt, Holy City of Medina.

107 Francis E. Peters, Jerusalem and Mecca: The Typology of the Holy City in the Near East (New York: New York University Press, 1986), 114. 
'Uthmān b. Abī al-'Āṣī al-Thaqafĩ bought the Shațt 'Uthmān [in Basra] from 'Uthmān b. 'Affān in exchange for some property in al-Ṭāiif; it is also said that it bought it in return for a residential court (dār) of his in Medina, which 'Uthmān b. 'Affān brought within the mosque when he enlarged it. 108

Medina was also the administrative and economic centre of the Umayyad Hijāz, a province to which many first-/seventh- and second-/eighth-century elites would have held a certain emotional attachment as their families' original homeland. On a practical level, the fact that the Hijāz was the land of origin for many elite families ensured that many of them continued to hold most of their estates in that region The Umayyads, however, were not an ordinary elite family. They controlled the office of the caliph, through which regional governors and other officials were often appointed, and this gave them unprecedented access to possibilities for acquiring land in other provinces beyond the Hijāz, possibilities not often open to other families. Their continuing interest in acquiring lands around Medina then still requires further explanation.

Several modern scholars have argued that land was the main basis for wealth and power, at least on the local level, in the pre-modern world. ${ }^{109}$ The more land in a family's possession, the less in the hands of their opponents and the more they could distribute to their own supporters to ensure their continuing loyalty. The Umayyads were not unaware of the importance of providing land for their supporters and taking it away from their opponents. The famous scholar and transmitter of reports about Muhammad's career, Ibn Shihāb al-Zuhrī, was among those granted estates in the northern Hijāz by the Marwanid caliphs in

108 Within al-Balādhurī, Futūḥ, 262. On al-Walīd b. Hishām al-Qaḥdhamī, see Wadād al-Qāḍī, "The Names of Estates in State Registers before and after the Arabization of the 'Dīwāns'," in Umayyad Legacies: Medieval Memories from Syria to Spain, eds. Antoine Borrut and Paul M. Cobb (Leiden: Brill, 2010), 255-280.

109 For example, Haldon, Byzantium, 129-130: "[P]ersonal wealth could only be secured beyond one generation through the acquisition of land. Landed property remained an essential element in securing one's future and also in cementing one's position within the establishment;" Walmsley, "Production," 316: "Here we see trade could serve as a source of wealth, but absolute richness and an esteemed social position was obtained by owning land." It should be noted, however, that as far as the early caliphate is concerned, some reservations about the social significance of land ownership beyond the local level have been expressed recently in a brief attempt to outline a model for the fiscal functioning of the caliphal state by Chris Wickham, "Tributary Empires: Late Rome and the Arab Caliphate," in Tributary Empires in Global History, eds. Peter Fibiger Bang and Christopher A. Bayly (Basingstoke: Palgrave Macmillan, 2011): "Landowning brought local status and power, at the level of the city, but this did not carry across to the level of the state." 
return for his loyal support. ${ }^{110}$ If anyone wanted to improve their own position of power in a given region at the expense of their opponents, somehow acquiring their land, whether legally or not, was one good way to go about it.

The basic usefulness of landholding for those who wished to achieve lasting wealth and power did not pass all Muslim scholars by. The Hanbali jurist alKhallāl (d. 311/923) offered two earlier opinions (among a great many others) which can suffice as examples here: the Medinan jurist Sa'id b. al-Musayyab (d. 94/713) was quoted saying that man can only be good by striving to maintain property through which he can pay his debts and keep his honor, and the Iraqi traditionist-jurisprudent Ahmad b. Hanbal (d. 241/855) encouraged the acquisition of estates and their proper management. ${ }^{111}$ Prophetic hadiths were also circulated which supported this advice, as were traditions which disapproved of the ownership of land. ${ }^{112}$

In this light, it is very instructive that the two families with whom the Umayyads appear to have come into conflict over property around Medina most frequently - the Alids and Zubayrids - were among their most dangerous rivals for the caliphal office itself. ${ }^{113}$ That the Hijāz was a region that required careful governance was acknowledged openly by political theorists at least by the mid-second/eighth century, ${ }^{114}$ and the earliest Abbasid caliphs certainly resorted to confiscating the lands of their opponents for the caliphal office in the Hijāz. To give just one example: after '̄̄sā b. Mūsā (d. 167/783-784) had suppressed the revolts of the Hasanid Alids Muhammad b. 'Abd Allāh b. al-Ḥasan and his brother Ibrāhīm, in Medina and Basra respectively in $145 / 762-763$, the caliph Abū Ja far al-Manșūr (r. 136-158/754-775) confirmed 'Īsā's confiscation of the Hasanids' estates. Some of them were later returned during the caliphate of Abū Ja'far's successor, Muhammad al-Mahdī (r. $15^{8-169 / 775-785)}{ }^{115}$ With these actions, the early Abbasid caliphs may well have been following earlier

\footnotetext{
110 Lecker, "Biographical Notes," 50-56.

111 Both are taken from within the wider discussion in Kister, "Land Property," 293-294; see also al-Khallāl, al-Hathth 'alā l-tijāra wa-l-șinā'a wa-l-'amal, ed. 'Abd al-Fattāḥ Abū Ghudda (Aleppo: Maktab al-mațbūāàt al-islāmiyya, 1415/1995), 5o, 29-32 (respectively).

112 See the general discussion in Kister, "Land Property."

113 On the Umayyads' competition with these two families in the Hijāz, see also now Ella Landau-Tasseron, "Arabia," in The New Cambridge History of Islam, vol. 1, The Formation of the Islamic World, Sixth to Eleventh Centuries, ed. Chase F. Robinson (Cambridge: Cambridge University Press, 2010), 405. For the Alid family in the Hijāz in particular, see now Ahmed, Religious Elite, $135^{-198 .}$

114 For example, Ibn al-Muqaffa', al-Risāla fí l-șahāäba, ed. and trans. Charles Pellat as: Ibn alMuqaffa, mortvers 140/757: "conseilleur" du calife (Paris: G.P. Maisonneuve et Larose, 1976), 6o-61.

115 al-Ṭabarī, Ta’rīkh, 3:257.
} 
Umayyad administrative precedence;"116 'Abd al-Malik (r. 65-86/685-705), for example, is said to have confiscated some Zubayrid properties in the aftermath of his defeat of 'Abd Allāh b. al-Zubayr in 73/692, although the same account stresses that he eventually returned them to Yahyā b. 'Urwa b. al-Zubayr. ${ }^{117}$

Sometimes there may have been a particular ideological issue at stake, as well as simple ownership of land. We have seen that 'Abd Allāh b. 'Amr b. 'Uthmān b. 'Affān incited 'Umar b. 'Abd al-Azīz against 'Urwa b. al-Zubayr by telling him that the latter was diverting travelers away from Marwān's well, the Umayyad family's water source. The provision of water to travelers and pilgrims was a prestigious role - one of the most important public "offices" of pre-Islamic Mecca was held to have been the siqa $y a$, overseeing the provision of water - and the Umayyads were annoyed that a rival family was performing this task with more success than them. ${ }^{118} \mathrm{~A}$ more obvious example of a specific concern involves the heir apparent (wali al-'ahd) al-Walīd b. Yazīd during the caliphate of his uncle, Hishām b. 'Abd al-Malik: al-Walīd ordered the trees on Ibn Shihāb al-Zuhri’s estate in the northern Hijāz to be cut down because the scholar had tried to convince Hishām to replace him in the line of succession. ${ }^{119}$

There was, of course, a balancing act going on. If caliphs or their governors took too rash a step towards appropriating others' property, open revolt might break out. The events leading up to the Battle of the Harra made this perfectly clear and it has been suggested that the widespread participation of leading Qurashī families, especially the Zubayrids, in the Alid revolt of Muhammad b. 'Abd Allāh in Medina against Abbasid rule in 145/762 was due to their resentment at recent policies that had undermined their landed wealth. ${ }^{120}$ As we have seen, the Umayyad caliphs al-Walīd b. 'Abd al-Malik and Hishām b. 'Abd al-Malik acted against members of their family's interests and reined in

116 That early Abbasid caliphs may have had considerable respect for the administrative policies of some of their Umayyad predecessors, see, for example, Antoine Borrut, "La 'memoria' omeyyade: les omeyyades entre souvenir et oubli dans les sources narratives islamiques," in Umayyad Legacies: Medieval Memories from Syria to Spain, eds. Antoine Borrut and Paul M. Cobb (Leiden: Brill, 2010), 46-50.

117 al-Zubayrī, Nasab Quraysh, 247.

118 Gerald H. Hawting, "The 'Sacred Offices' of Mecca from Jāhiliyya to Islam," Jerusalem Studies in Arabic and Islam 13 (1990): 62-84. For the significance attached by Abbasid caliphs to this duty, see now Travis Zadeh, "The Early Hajj: Seventh-Eighth Centuries CE," in The Hajj: Pilgrimage in Islam, eds. Eric Tagliacozzo and Shawkat M. Toorawa (Cambridge: Cambridge University Press, 2016), 44-45, 49-51, 56-57, 59-6o, 62-64.

119 Lecker, "Biographical Notes," 54.

120 Amikam Elad, "The Rebellion of Muḥammad b. 'Abd Allāh b. al-Ḥasan (Known as al-Nafs al-Zakīya) in 145/762," in 'Abbasid Studies: Occasional Papers of the School of 'Abbasid Studies, Cambridge, 6-10 July 2002, ed. James E. Montgomery (Leuven: Peeters, 2004), 185. 
their respective governors of Medina when they acted overzealously in infringing the property rights of 'Urwa b. al-Zubayr and his sons. Their father, 'Abd al-Malik, had tried hard to reconcile 'Urwa to Umayyad rule after his successful defeat of the latter's brother, 'Abd Allāh b. al-Zubayr's, rival caliphate in the Hijāz. ${ }^{121} \mathrm{Al}-W a l i ̄ d$ and Hishām would not have wanted to see their father's hard work brought to nothing. The balancing act had to be carefully maintained, but activities that gradually increased Umayyad-owned land around Medina while reducing the amount in the hands of the Zubayrids and the Alids served a clear purpose: it reduced the principal base of the wealth, and hence the potential political power, of two notable families who, had they been left alone to consolidate their position as prominent Hijāzī landholders, could have been even more serious rivals for the caliphal office. Landholding around Umayyad-era Medina was very much connected to questions of authority and control.

\section{Acknowledgements}

I am very grateful to Chase Robinson, Michael Lecker, Nicola Clarke and Nick Chatrath for their comments on earlier drafts of this paper, and to all those who attended the colloquium for their helpful suggestions. I would especially like to thank the conveners of that colloquium and editors of the present volume.

\section{Bibliography}

\section{Primary Sources}

Abū l-'Arab (d. 333/944-945). Kitāb al-mihan. Edited by Yahyā Wahīb al-Jabūrī. 2nd edition. Beirut: Dār al-gharb al-islāmī, 1988 [= 1408].

Abū Yūsuf (d. 182/798). Kitāb al-kharāj. Cairo: al-Mațba'a al-mīriyya, 1884-1885 [=1302]. al-Balādhurī (d. ca. 279/892-893). Kitāb futūh al-buldān. Edited by M.J. de Goeje as: Liber expugnationis regionum. Leiden: Brill, 1866.

al-Balādhurī. Ansāb al-ashrāf, vol. 4, no. 1. Edited by Iḥsān 'Abbās. Beirut: Franz Steiner, $1979[=1400]$.

al-Fīrūzābādī (d. 817/1415). al-Maghānim al-muțāba fìmacālim Ṭāba (qism al-mawādọi).

Edited by Ḥamad al-Jāsir. Riyadh: Dār al-Yamāma, 1969 [= 1389].

121 Gregor Schoeler, "Urwa b. al-Zubayr," in Encyclopaedia of Islam, 2nd ed. (Leiden: Brill), http://dx.doi.org/10.1163/1573-3912_islam_COM_1305. 
Ibn 'Asākir (d. 571/1176). Ta'rīkh madīnat Dimashq. Edited by 'Alī Shīrī and 'Umar al'Amrawī. 8o vols. Beirut: Dār al-fikr, 1995-200o [= 1415-1421].

Ibn al-Faqīh (wr. ca. 289-29o/9o2-903). Mukhtașar Kitāb al-buldān. Edited by M.J. de Goeje. Leiden: Brill, 1885 .

Ibn Ḥajar al-'Asqalānī (d. 852/1449). Fatḥ al-bārū sharh Ṣaḥ̄h al-Bukhārī. New edition. 16 vols. Edited by 'Abd al-'Azīz ibn Bāz and Muḥammad Fu’ād 'Abd al-Bāqī. Beirut: Dār al-kutub al-'ilmiyya, 1989 [= 1410].

Ibn al-Muqaffa' (d. ca. 139/756-757). al-Risāla fi l-ṣahāaba. Edited and translated by Charles Pellat as: Ibn al-Muqaffa, mort vers 140/757: "conseilleur" du calife. Paris: G.P. Maisonneuve et Larose, 1976.

Ibn Qutayba (attrib.). Kitāb al-imāma wa-l-siyāsa. 2 vols. Cairo: Maṭba'at al-Nīl, 1904 [= 1322].

Ibn Sa'd (d. 23o/845). Kitāb al-țabaqāt al-kubrāa. 8 vols. Beirut: Dār șādir, 196o-1968 [= 1380-1388].

Ibn Shabba (d. 262/876). Ta'rīkh al-Madīna al-munawwara. Edited by 'Alī Muhammad Dandal and Yāsīn Sa`d al-Dīn Bayān. 2 vols. Beirut: Dār al-kutub al-ilmiyya, 1996 [= 1417].

al-Ișțakhrī (wr. ca. second quarter of fourth/tenth century). Kitāb al-masālik wa-lmamālik. Edited by M.J. de Goeje. Leiden: Brill, 1870 .

al-Jahshiyārī (d. 331/942). Kitāb al-wuzarā’ wa-l-kuttāb. Edited by Muṣțafā al-Saqqā et al. Cairo: Muștafā al-Bābī al-Ḥalabī, 1938 [= 1357].

al-Khallāl (d. 311/923). al-Hathth 'alā l-tijāra wa-l-șinā'a wa-l-'amal. Edited by 'Abd alFattāḥ Abū Ghudda. Aleppo: Maktab al-mațbūāt al-islāmiyya, 1995 [= 1415].

Lughda al-Ișfahānī (wr. mid-to-late third/ninth century). Bilād al-'arab. Edited by Ṣāliḥ Aḥmad al-'Alī and Ḥamad al-Jāsir. Riyadh: Dār al-Yamāma, 1968 [= 1388].

al-Mizzī (d. 742/1341). Tahdhīb al-Kamāl fi asmā’ al-rijāl. Edited by Bashshār 'Awwād Ma'rūf. 35 vols. Beirut: Mu’assasat al-risāla, 1982-1992 [= 1402-1413].

al-Mubarrad (d. ca. 286/899-90o). al-Kitāb al-kāmil. Edited by William Wright. 12 parts in 2 vols. Leipzig: F.A. Brockhaus, $1874-1892$.

al-Muqaddasī (wr. late fourth/tenth century). Ahssan al-taqāsìm fì ma'rifat al-aqālìm. 2nd edition. Edited by M.J. de Goeje. Leiden: Brill, 1906.

al-Samhūdī (d. 911/1506). Wafä̀ al-wafā bi-akhbār dār al-muștafā. Edited by Qāsim alSāmarrā'̀̄. 5 vols. London: Mu'assasat al-furqān, 2001 [= 1422].

al-Ṭabarī (d. 310/923). Ta'rīkh al-rusul wa-l-mulūk. Eds. M.J. de Goeje et al. as: Annales quos scripsit Abu Djafar Mohammed ibn Djarir at-Tabari. 3 parts in 13 vols. Leiden: Brill, 1879-1901.

al-Tha'labī (d. 427/1035). al-Kashf wa-l-bayān (Tafsīr al-Tha'labī). Edited by Abū Muḥammad ibn 'Āshūr. 10 vols. Beirut: Dār ihyyā' al-turāth al-'arabī, 2002 [= 1422]. Wakī' (d. 3o6/918). Akhbār al-qudạt. Edited by 'Abd al-'Azīz al-Marāghī. 3 vols. Cairo: Mațba'at al-istiqāma, 1947-1950 [= 1366-1369]. 
al-Ya'qūbī (d. ca. 292/904-905). Ta’rīkh. Edited by T. Houtsma as: Ibn-Wādhih qui dicitur al-Ja'qubī Historiae. 2 vols. Leiden: Brill, 1883.

al-Ya'qūbī. Kitāb al-buldān. Edited by M.J. de Goeje. Leiden: Brill, 1892.

Yāqūt (d. 626/1229). Mu'jam al-buldān. Edited by Ferdinand Wüstenfeld as: Jacut's geographisches Wörterbuch. 6 vols. Leipzig: F.A. Brockhaus, 1866-1873.

al-Zubayrī (d. 236/851). Kitāb nasab Quraysh. Edited by E. Levi-Provençal. 4th edition. Cairo: Dār al-ma‘ārif, n.d.

\section{Secondary Sources}

Ahmed, Asad Q. The Religious Elite of the Early Islamic Hijäz: Five Prosopographical Case Studies. Oxford: Unit for Prosopographical Research, 2011.

al-'Alī, Șālị̣ Aḥmad. "Muslim Estates in Hidjaz in the First Century A.H." Journal of the Economic and Social History of the Orient 2 (1959): 247-261.

al-'Alī, Șāliḥ Aḥmad. "Studies in the Topography of Medina (During the first Century A.H.)." Islamic Culture 35 (1961): 65-92.

al-'Alī, Ṣāliḥ Aḥmad. "Milkiyyāt al-arāḍī fī l-Ḥijāz fĩ l-qarn al-awwal al-hijrī." Majallat al-'arab 3 (1389/1969): 961-1005.

Arazi, Albert. "Matériaux pour l'étude du conflit de préséance entre la Mekke et Médine." Jerusalem Studies in Arabic and Islam 5 (1984): 177-235.

Ashtor, Eliyahu. A Social and Economic History of the Near East in the Middle Ages. London: Collins, 1976.

Askūbī, Khālid b. Muhammad. "Archaeological Survey of Western Al-Madinah alMunawwarah, 1424A.H.-2004A.D. Season." Ațlāl 20 (1431/2010): 151-165.

Avner, Uzi, and Jodi Magness. "Early Islamic Settlement in the Southern Negev." Bulletin of the American Schools of Oriental Research 310 (1998): 39-57.

Bacharach, Jere L. "Marwanid Umayyad Building Activities: Speculations on Patronage." Muqarnas 13 (1996): 27-44.

Banaji, Jairus. Agrarian Change in Late Antiquity: Gold, Labour, and Aristocratic Dominance. 2nd edition. Oxford: Oxford University Press, 2007.

Banaji, Jairus. "Aristocracies, Peasantries and the Framing of the Early Middle Ages." Journal of Agrarian Change 9 (2009): 59-91.

Banaji, Jairus. "Late Antique Legacies and Muslim Economic Expansion." In Money, Power and Politics in Early Islamic Syria: A Review of Current Debates, edited by John F. Haldon, 165-179. Farnham: Ashgate, 2010.

Blankinship, Khalid Yahya. The End of the Jihad State: The Reign of Hisham ibn Abd alMalik and the Collapse of the Umayyads. Albany, NY: State University of New York Press, 1994 .

Borrut, Antoine. “La 'memoria' omeyyade: les omeyyades entre souvenir et oubli dans les sources narratives islamiques." In Umayyad Legacies: Medieval Memories from Syria to Spain, edited by Antoine Borrut and Paul M. Cobb, 25-61. Leiden: Brill, 2010. 
Borrut, Antoine. Entre mémoire et pouvoir: l'espace syrien sous les derniers Omeyyades et les premiers Abbassides. Leiden: Brill, 2011.

Cahen, Claude. "Day'a". In Encyclopaedia of Islam, 2nd edition. Edited by P. Bearman, Th. Bianquis, C.E. Bosworth, E. van Donzel and W.P. Heinrichs. Leiden: Brill. http:// dx.doi.org/10.1163/1573-3912_islam_SIM_1763.

Clarke, Nicola. The Muslim Conquest of Iberia: Medieval Arabic Narratives. London: Routledge, 2012.

Crone, Patricia, and Martin Hinds. God's Caliph: Religious Authority in the First Centuries of Islam. Cambridge: Cambridge University Press, 1986.

Crone, Patricia. Meccan Trade and the Rise of Islam. Oxford: Blackwell, 1987.

Decker, Michael. Tilling the Hateful Earth: Agricultural Production and Trade in the Late Antique East. Oxford: Oxford University Press, 2009.

al-Dūrī, 'Abd al-'Azīz. "Landlord and Peasant in Early Islam: A Critical Study." Der Islam 56 (1979): 97-105.

Elad, Amikam. "The Rebellion of Muhammad b. 'Abd Allāh b. al-Ḥasan (Known as alNafs al-Zakiya) in 145/762." In 'Abbasid Studies: Occasional Papers of the School of 'Abbasid Studies, Cambridge, 6-10 July 2002, edited by James E. Montgomery, 147198. Leuven: Peeters, 2004.

Elad, Amikam. "The Struggle for Legitimacy of Authority as Reflected in the Hadith of al-Mahdī." In 'Abbasid Studies II: Occasional Papers of the School of Abbasid Studies, Leuven, 28 June-1 July 2004, edited by John Nawas, 39-96. Leuven: Peeters, 2010.

El-Hibri, Tayeb. Parable and Politics in Early Islamic History: The Rashidun Caliphs. New York: Columbia University Press, 2010.

Feissel, Denis. "Jean de Soloi, un évêque chypriote au milieu du VII ${ }^{\mathrm{e}}$ siècle." Travaux et mémoire 17 (2013): 219-236.

Flusin, Bernard. "Démons et sarrasins: l'auteur et le propos des Diègèmata stèriktika d'Anastase le Sinaïte." Travaux et mémoire 11 (1991): 381-409.

Foss, Clive. "Egypt under Mu'āwiya," Bulletin of the School of Oriental and African Studies 72 (2009): 1-24, 259-278.

Fowden, Garth. Qușayr Amra: Art and the Umayyad Elite in Late Antique Syria. Berkeley: University of California Press, 2004.

Genequand, Denis. "Formation et devenir du paysage architectural omeyyade: l' apport de l'archéologie." In Umayyad Legacies: Medieval Memories from Syria to Spain, edited by Antoine Borrut and Paul M. Cobb, 417-473. Leiden: Brill, 2010.

Gilmore, Michael, Mohammed Al-Ibrahim and Abduljawwad S. Murad. "Preliminary Report on the Northwestern and Northern Region Survey 1981 (1401)." Ațläl 6 (1982): 9-23.

Haldon, John F. Byzantium in the Seventh Century: The Transformation of a Culture. 2nd edition. Cambridge: Cambridge University Press, 1997. 
Haque, Ziaul. Landlord and Peasant in Early Islam: A Study of the Legal Doctrine of Muzāra'a or Sharecropping. Islamabad: Islamic Research Institute, 1977.

Hasson, Isaac. "Contributions à l'étude des Aws et des Hazrağ." Arabica 36 (1989): 135 .

al-Hawas, Fahd bin Saleh, et al. "Preliminary Report on the Excavations of the Islamic Site of Faid, Hail Region, First Season, 1427 A.H./2006 A.D." Ațlāl 20 (2010): 39-74.

Hawting, Gerald R. "The 'Sacred Offices' of Mecca from Jāhiliyya to Islam." Jerusalem Studies in Arabic and Islam 13 (1990): 62-84.

Heck, Gene W. "Gold Mining in Arabia and the Rise of the Islamic State." Journal of the Economic and Social History of the Orient 42 (1999): 364-395.

Hinz, Walther. Islamische Masse und Gewichte umgerechnet ins metrische System. Leiden: Brill, 1955.

Hoyland, Robert G. Seeing Islam as Others Saw It: A Survey and Evaluation of Christian, Jewish and Zoroastrian Writings on Early Islam. Princeton: Darwin Press, 1997.

Hoyland, Robert G. Theophilus of Edessa's Chronicle and the Circulation of Historical Knowledge in Late Antiquity and Early Islam. Liverpool: Liverpool University Press, 2011.

al-Jāsir, Hamad. Fī shamāl gharb al-jazīra: nuṣuṣs, mushāhadāt, ințibā āt. Riyadh: Dār alYamāma, 1390/1970.

Kennedy, Hugh. "The Feeding of the Five Hundred Thousand: Cities and Agriculture in Early Islamic Mesopotamia." Iraq 73 (2011): 177-199.

Khan, Ahmad. "The Tanning Cottage Industry in Pre-Islamic Arabia." Journal of the Pakistan Historical Society 19 (1971): 85-100.

Kister, Meir J. "The Social and Political Implications of Three Traditions in the Kitāb alKharādj of Yahya b. Adam." Journal of the Economic and Social History of the Orient 3 (1960): 326-334.

Kister, Meir J. "Some Reports Concerning Mecca: From Jāhiliyya to Islam." Journal of the Economic and Social History of the Orient 15 (1972): 61-93.

Kister, Meir J. "The Battle of the Harra: Some Socio-Economic Aspects." In Studies in Memory of Gaston Wiet, edited by Myriam Rosen-Ayalon, 33-49. Jerusalem: The Hebrew University of Jerusalem, 1977.

Kister, Meir J. "The Massacre of the Banū Qurayza:a: A Re-examination of a Tradition." Jerusalem Studies in Arabic and Islam 8 (1986): 61-96.

Kister, Meir J. "Land Property and Jihād: A Discussion of Some Early Traditions." Journal of the Economic and Social History of the Orient 34 (1991): 270-311.

Lambton, Ann K.S. "Șafì (pl. safāyā), Șawāfì." In Encyclopaedia of Islam, 2nd edition. Edited by P. Bearman, Th. Bianquis, C.E. Bosworth, E. van Donzel and W.P. Heinrichs. Leiden: Brill. http://dx.doi.org/10.1163/1573-3912_islam_SIM_6444.

Lammens, Henri. Études sur le règne du calife omaiyade Mo'âwia I ${ }^{\text {er }}$. Paris: Paul Geuthner, 1908. 
Lammens, Henri. "Le califat de Yazîd I ${ }^{\mathrm{er}}$." Mélanges de l'Université Saint Joseph 4 (1910): 233-312; 5 (1910-1912): 79-269, 589-724; 6 (1913): 401-497.

Landau-Tasseron, Ella. “Arabia." In The New Cambridge History of Islam, vol. 1, The Formation of the Islamic World, Sixth to Eleventh Centuries, edited by Chase F. Robinson, 397-447. Cambridge: Cambridge University Press, 2010.

Lane, Edward W. Arabic-English Lexicon. 8 vols. London: Williams and Norgate, 18631893 .

Lecker, Michael. The Banū Sulaym: A Contribution to the Study of Early Islam. Jerusalem: The Hebrew University of Jerusalem, 1989.

Lecker, Michael. Muslims, Jews and Pagans: Studies on Early Islamic Medina. Leiden: Brill, 1995.

Lecker, Michael. "Biographical Notes on Ibn Shihāb al-Zuhrī." Journal of Semitic Studies 41 (1996): 21-63.

Lecker, Michael. "Were the Jewish Tribes in Arabia Clients of Arab Tribes?" In Patronate and Patronage in Early and Classical Islam, edited by Monique Bernards and John Nawas, 50-69. Leiden: Brill, 2005.

Lynch, Ryan J. "Cyprus and Its Legal and Historiographical Significance in Early Islamic History." Journal of the American Oriental Society 136 (2016): 535-550.

Mayerson, Philip. "The Port of Clysma (Suez) in Transition from Roman to Arab Rule." Journal of Near Eastern Studies 55 (1996): 119-126.

Miles, George C. "Early Islamic Inscriptions near Ṭā’if in the Hijāz." Journal of Near Eastern Studies 7 (1948): 236-242.

Millward, William G. "The Adaptation of Men to Their Time: An Historical Essay by al-Ya'qūbī." Journal of the American Oriental Society 84 (1964): 329-344.

Milwright, Marcus. An Introduction to Islamic Archaeology. Edinburgh: Edinburgh University Press, 2010.

Munt, Harry. "Writing the History of an Arabian Holy City: Ibn Zabāla and the First Local History of Medina." Arabica 59 (2012): 1-34.

Munt, Harry. The Holy City of Medina: Sacred Space in Early Islamic Arabia. Cambridge: Cambridge University Press, 2014.

Noth, Albrecht. "Eine Standortbestimmung der Expansion (Futūh) unter den ersten Kalifen (Analyse von Ṭabarī I, 2854-2856).” Asiatische Studien 43 (1989): 120136.

Peters, Francis E. Jerusalem and Mecca: The Typology of the Holy City in the Near East. New York: New York University Press, 1986.

al-Qāḍī, Wadād. "The Names of Estates in State Registers before and after the Arabization of the 'Dīwāns'." In Umayyad Legacies: Medieval Memories from Syria to Spain, edited by Antoine Borrut and Paul M. Cobb, 255-280. Leiden: Brill, 2010.

al-Rashid, Saad. al-Rabadhah: A Portrait of Early Islamic Civilisation in Saudi Arabia Riyadh: King Saud University, n.d. [1986]. 
al-Rashid, Saad. Dirāsāt fì l-āthār al-islāmiyya al-mubakkira bi-l-Madīna al-munawwara. Riyadh: Mu'assasat al-Huzaymī, 2000 [= 1421].

Robinson, Chase F. Empire and Elites after the Muslim Conquest: The Transformation of Northern Mesopotamia. Cambridge: Cambridge University Press, 2000.

Schoeler, Gregor. "Urwa b. al-Zubayr." In Encyclopaedia of Islam, 2nd edition. Edited by P. Bearman, Th. Bianquis, C.E. Bosworth, E. van Donzel and W.P. Heinrichs. Leiden: Brill. http://dx.doi.org/10.1163/1573-3912_islam_COM_1305.

Sijpesteijn, Petra. "Landholding Patterns in Early Islamic Egypt." Journal of Agrarian Change 9 (2009): 120-133.

Sijpesteijn, Petra. Shaping a Muslim State: The World of a Mid-Eighth-Century Egyptian Official. Oxford: Oxford University Press, 2013.

Veccia Vaglieri, L. "Fadak." In Encyclopaedia of Islam, 2nd edition. Edited by P. Bearman, Th. Bianquis, C.E. Bosworth, E. van Donzel and W.P. Heinrichs. Leiden: Brill. http://dx.doi.org/10.1163/1573-3912_islam_SIM_2218.

Walmsley, Alan. "Production, Exchange and Regional Trade in the Islamic East Mediterranean: Old Structures, New Systems?" In The Long Eighth Century, edited by Inge Hansen and Chris Wickham, 264-343. Leiden: Brill, 2000.

Watson, Andrew M. Agricultural Innovation in the Early Islamic World: The Diffusion of Crops and Farming Techniques, 700-1100. Cambridge: Cambridge University Press, 1983.

Wickham, Chris. Framing the Early Middle Ages: Europe and the Mediterranean, 40o80o. Oxford: Oxford University Press, 2005.

Wickham, Chris. “Tributary Empires: Late Rome and the Arab Caliphate." In Tributary Empires in Global History, edited by Peter Fibiger Bang and Christopher A. Bayly, 205-213. Basingstoke: Palgrave Macmillan, 2011.

al-Wohaibi, Abdullah. The Northern Hijaz in the Writings of the Arab Geographers, 80o1150. Beirut: al-Risalah, 1973 .

Zadeh, Travis. "The Early Hajj: Seventh-Eighth Centuries CE." In The Hajj: Pilgrimage in Islam, edited by Eric Tagliacozzo and Shawkat M. Toorawa, 42-64. Cambridge: Cambridge University Press, 2016. 